\title{
Asbestos bodies in the lung: Southampton (UK) and Wellington (New Zealand)
}

\author{
R H STEELE AND K J THOMSON \\ From the Department of Pathology, University of Queensland, Department of Pathology, Wellington Clinical \\ School of Medicine, University of Otago, and Department of Pathology, Southampton University Medical \\ School, Southampton, UK
}

ABSTRACT Two series of surgically removed and unselected necropsy lungs were examined for asbestos bodies. In the series from Southampton (UK) $30-\mu$ sections were used and in the Wellington (New Zealand) series a modified Gold's digestion method was used for all cases, together with $30-\mu$ sections for some. A further series of Southampton lungs was assessed by Gold's method six years after the initial study. The 30- $\mu$ section technique found asbestos bodies in $13 \%$ of Southampton men and none in women: the corresponding Wellington figures were $8 \%$ for men and nil for women. In Wellington the more sensitive digestion method found asbestos bodies in $78 \%$ of men and $63 \%$ of women. In Southampton the investigation by Gold's method found asbestos bodies in $83 \%$ of men and $74 \%$ of women. No statistically significant association was found between the number of asbestos bodies and the various types of lung carcinoma. The prevalence of asbestos in lungs removed between 1956 and 1965 did not differ significantly from its prevalence in those removed in the late 1970s. There was no significant increase in asbestos after the age of 20 .

In 1970 one of us (KJT) was co-author of a report on asbestos bodies in the lungs of Dunedin (New Zealand) necropsy cases. ${ }^{1}$ Two methods were used to identify them. Unstained $30-\mu$ thick sections found $3 \%$ of cases to be positive, but Gold's digestion method, ${ }^{2}$ slightly modified, showed asbestos bodies in $85 \%$ of cases. This report concerns asbestos bodies in surgically removed lungs, mostly with primary tumours, and in unselected necropsy lungs from two centres on opposite sides of the world. The initial Southampton material was examined by $30-\mu$ sections only, but some of the Wellington material was examined by both methods, and a subsequent series of Southampton lungs in 1981 was also digested by Gold's method. In Wellington surgically removed lungs dating back to as early as 1956 were available for study, and it was possible to compare the frequency of retained asbestos in the lungs of different decades. These early lungs had been kept inflated in formalin, but as many had partially dried out they were not considered suitable for histological sectioning.

Received 4 December 1980

Accepted 29 March 1982

\section{Materials and methods}

In Southampton 212 surgically removed lungs or lobes containing neoplasms were examined by one of us (RHS) between 1973 and 1975. When the whole lung was available two $30-\mu$ sections, each $3 \times 2.5 \mathrm{~cm}$ in area, were cut from the posterior basal segment, but when only an upper or middle lobe had been removed, sections were taken from the most dependent part available. These sections were examined unstained. In additon, 107 male necropsy cases unselected but without primary lung tumours were examined in the same manner. The ages of these subjects ranged from 16 to 92 years.

In Wellington 248 lungs were examined by Gold's digestion method, slightly modified, as described below. Of these, 98 that had been removed fresh in 1976 and 1977 were also examined by $30-\mu$ unstained sections. The lungs in Wellington were mostly surgical specimens removed from 1956 onwards, and were otherwise unselected. Of the 167 lungs containing primary epithelial lung tumours, eight were metastatic carcinomas, two nonepithelial neoplasms, and 71 non-neoplastic conditions, of which 36 were from unselected necropsies 349 
and 35 were operative specimens. The ages of the Wellington subjects ranged from 14 to 92 . Neither series contained any cases suffering from asbestosis or with a known history of exposure to asbestos.

The method of digestion used was to take $0.4 \mathrm{~g}$ of each lung, which we found was the average weight of a dozen blocks each one cubic centimetre in volume. A constant volume was not taken because the degree of inflation of the specimens varied considerably. The tissues were digested for three hours in $40 \% \mathrm{KOH}$ at $60^{\circ} \mathrm{C}$, then washed three times with distilled water, the residue resuspended by vibrator and stained with Perls' method for iron. After three further washings the deposited material was spread out on two slides, one of which was examined by each investigator. Our analysis is based on the sum of the number of bodies seen in the two slides. As in the previous Dunedin study only typically segmented bodies or those with expanded ends were counted; objects with dark or yellow centres were specifically excluded. The results were expressed as asbestos bodies per $\mathrm{cm}^{3}$ to enable better comparison with other studies.

\section{Results}

The Southampton and Wellington results by the $30-\mu$ section method are summarised in table 1 . No female cases were positive by this method in either centre.

The surgical cases were on average three years younger than the necropsy cases, but in each instance the patients with asbestos in the lungs were very much the same age as those without.

\section{DIGESTION METHOD RESULTS (WELLINGTON}

ONLY)

Among the 248 specimens examined, at least one typical body was found in 187 , an overall prevalence of $75 \%$ (table 3 ). The actual number of bodies seen
Table 2 Comparison of Gold's method with 30- $\mu$ sections (Wellington results)

\begin{tabular}{lccc}
\hline $\begin{array}{l}\text { Gold's method } \\
\left.\text { (bodies } / \mathrm{cm}^{3}\right)\end{array}$ & \multicolumn{2}{l}{$\begin{array}{l}30-\mu \text { sections } \\
(\text { bodies } / \text { sections }\end{array}$} & $3 \times 2.5 \mathrm{~cm})$ \\
\cline { 2 - 4 } & 0 & 1 & 5 or more \\
\hline Nil & 21 & 3 & \\
$1-9$ & 47 & 3 & \\
$10-49$ & 21 & & 1 \\
$50-99$ & 2 & & 2 \\
$\geqslant 100$ & 1 & 3 & 3 \\
Total & 92 & 3 \\
\hline
\end{tabular}

varied from 0 to $13680 / \mathrm{cm}^{3}$ and we have divided them into negatives, those with light contamination (1-9 bodies $\left./ \mathrm{cm}^{3}\right)$, moderate contamination (10-99 bodies $/ \mathrm{cm}^{3}$ ), and heavily contaminated (100 or more bodies $/ \mathrm{cm}^{3}$ ). It should be emphasised here that the numbers seen, even in the heavily contaminated lungs, are very low when compared with the levels found in asbestosis.

A comparison of Gold's method with the $30-\mu$ section method in the 98 cases suitable for investigation by both methods showed poor correlation (table 2).

Significantly more of the heavily contaminated cases were male (table 3 ). For the analysis of this table Bartholomew's test, ${ }^{3}$ a modification of the familiar Chi-squared test, was chosen because it takes account of the fact that the categories of asbestos contamination were arranged in order of increasing intensity. When applied to table 3 the test statistic is $13.6(\mathrm{p}<0.01)$.

The ages of these subjects ranged from 15-92 years. Five lungs came from subjects under 20 and two of these (17-year-old boys) contained fewer than 10 asbestos bodies $/ \mathrm{cm}^{3}$. Including these, there were 15 subjects aged under 30 and of these, 12 were positive $(80 \%)$, four $(26.6 \%)$ having moderate contamination. Analysis of each subsequent decade of age showed no significant trend in asbestos contamination. A man of 33 with a squamous car-

Table 1 Prevalence of asbestos bodies by 30- $\mu$ section technique

\begin{tabular}{|c|c|c|c|c|c|c|}
\hline & $\begin{array}{l}\text { Non-malignant } \\
\text { (postmortem) }\end{array}$ & $\begin{array}{l}\text { Squamous } \\
\text { carcinoma }\end{array}$ & Adenocarcinoma & $\begin{array}{l}\text { Small cell } \\
\text { carcinoma }\end{array}$ & Others & Total \\
\hline \multicolumn{7}{|l|}{$\begin{array}{l}\text { Southampton } \\
\text { Men }\end{array}$} \\
\hline $\begin{array}{l}\text { Positive } \\
\text { Negative }\end{array}$ & $\begin{array}{l}11(10 \%) \\
96\end{array}$ & $21(17 \%)$ & $\underset{15}{5}(25 \%)$ & $\begin{array}{r}0 \\
20\end{array}$ & 12 & $\begin{array}{r}38(13 \%) \\
248\end{array}$ \\
\hline $\begin{array}{l}\text { Women } \\
\text { Positive } \\
\text { Negative }\end{array}$ & - & $\begin{array}{r}0 \\
11\end{array}$ & $\begin{array}{r}0 \\
10\end{array}$ & $\begin{array}{l}0 \\
9\end{array}$ & $\begin{array}{l}\mathbf{0} \\
3\end{array}$ & $\begin{array}{r}0 \\
33\end{array}$ \\
\hline $\begin{array}{l}\text { Wellington } \\
\text { Men }\end{array}$ & (surgical) & & & & & \\
\hline $\begin{array}{l}\text { Positive } \\
\text { Negative } \\
\text { Women }\end{array}$ & $\begin{array}{l}0 \\
5\end{array}$ & $45(4 \%)$ & $\begin{array}{r}2(12 \%) \\
14\end{array}$ & $\begin{array}{l}2(25 \%) \\
6\end{array}$ & $\overline{-}$ & $\begin{array}{l}6(8 \%) \\
70\end{array}$ \\
\hline $\begin{array}{l}\text { Positive } \\
\text { Negative }\end{array}$ & $\begin{array}{l}0 \\
5\end{array}$ & $\begin{array}{l}0 \\
5\end{array}$ & $\begin{array}{l}0 \\
6\end{array}$ & $\begin{array}{l}0 \\
4\end{array}$ & $\begin{array}{l}0 \\
2\end{array}$ & $\begin{array}{r}0 \\
22\end{array}$ \\
\hline
\end{tabular}


Table 3 Wellington cases by Gold's method. (Compared for sex and number of asbestos bodies)

\begin{tabular}{llrrrr}
\hline & Negative & Light & Moderate* & Heavy* \\
\hline Men & $43(22 \%)$ & $83(42 \%$ & $59(30 \%)$ & $11(6 \%)$ & 196 \\
Women & $18(37 \%)$ & $29(58 \%)$ & $4(8 \%)$ & $12 \%)$ & $12(5 \%)$ \\
Total & $61(25 \%)$ & $112(45 \%)$ & $63(25 \%)$ & 248 & 12 \\
\hline
\end{tabular}

Bartholomew's statistic ${ }^{3} \quad\left\{\chi_{4}^{-2}\right\}=13.6 \mathrm{p}<0.01$.

* See text for definition.

Table 4 Wellington cases by Gold's method: compared for tumour and type

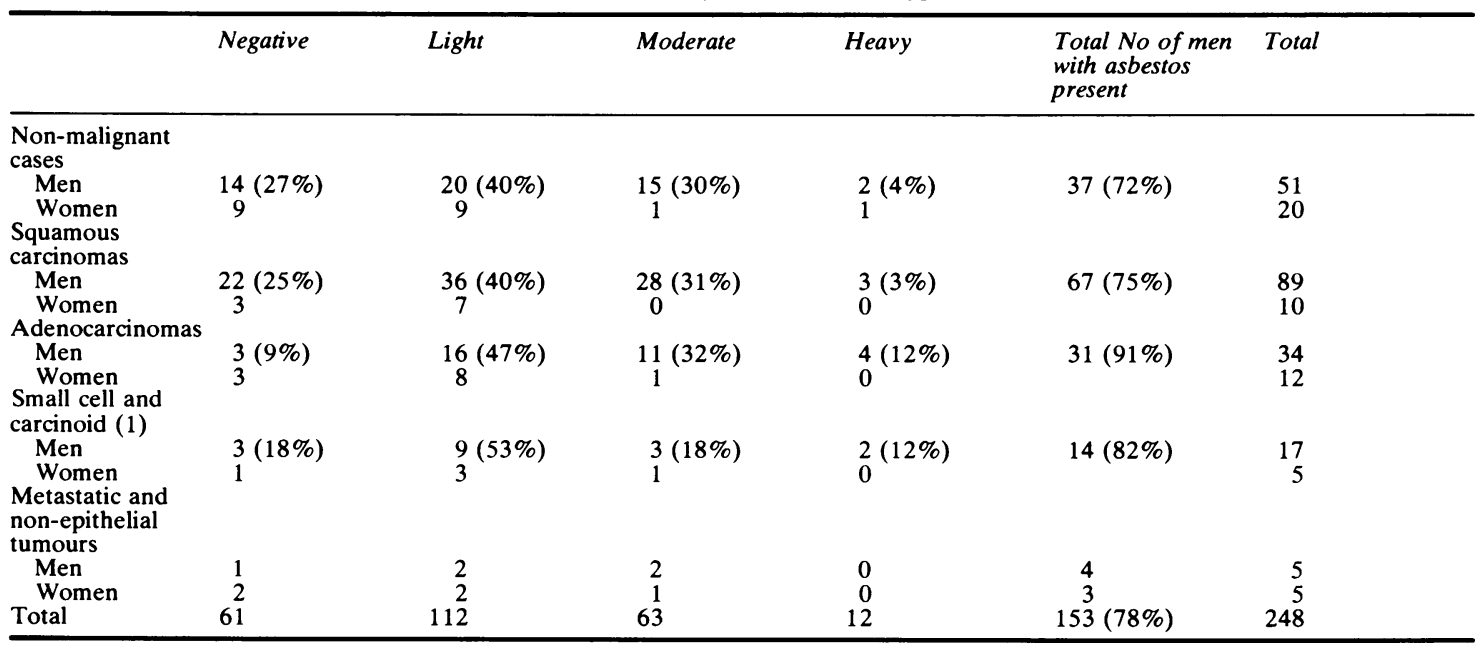

Table 5 Southampton cases (1981) by Gold's method

\begin{tabular}{lrlrrr}
\hline & Negative & Light & Moderate & Heavy \\
\hline Men & $13(17 \%)$ & $23(30 \%)$ & $21(28 \%)$ & $18(24 \%)$ & 0 \\
Women & $8(26 \%)$ & $19(61 \%)$ & $4(13 \%)$ & 75 & 31 \\
Total & $21(20 \%)$ & $42(40 \%)$ & $25(24 \%)$ & $18(17 \%)$ & 106 \\
\hline
\end{tabular}

cinoma was the youngest to have over 100 asbestos bodies $/ \mathrm{cm}^{3}$.

The results for the male and female cases classified according to the presence and type of primary tumour are presented in table 4 . The group with malignancies showed neither heavier nor more frequent contamination with asbestos than the benign. The trend towards heavier contamination in the lungs with adenocarcinoma was not significant at the 5\% level (Bartholomew's test).

Twenty-six lungs were removed before 1965 and of these, $69 \%$ contained asbestos and $19 \%$ had more than light contamination. This is not significantly less than the $75 \%$ contamination of lungs removed after $1975,27 \%$ of which had at least 10 bodies $/ \mathrm{cm}^{3}$.

\section{DIGESTION METHOD RESULTS, SOUTHAMPTON} 1981

In 1981 the opportunity occurred for one of us (RHS) to examine a second series of Southampton lungs, this time by the same modified Gold's method that we had used in Wellington. Twelve of the 50 male lungs containing neoplasms had more than 100 asbestos bodies $/ \mathrm{cm}^{3}$ and nine were negative (table 5). The 10 cases of adenocarcinoma did not contain significantly more asbestos than the series as a whole. Two cases of mesothelioma were included, however, and both had over 1000 bodies $/ \mathrm{cm}^{3}$, as did two cases of carcinoma who also had pleural plaques.

A series of 31 female lungs examined in Southampton at the same time included no heavily contaminated cases and only four moderately so; 
Table 6 Earlier reports of asbestos body prevalence

\begin{tabular}{|c|c|c|c|c|c|}
\hline Place & Method of detection & $\begin{array}{l}\text { No in } \\
\text { series }\end{array}$ & $\%$ positive & Population examined & Special comments \\
\hline France $^{10}$ & $\begin{array}{l}\text { Digestion and micro } \\
\text { filtration }\end{array}$ & 100 & $100 \%$ & $\begin{array}{l}69 \text { Necropsies } \\
31 \text { Surgical }\end{array}$ & $\begin{array}{l}\text { Prevalence increased with age } \\
\text { and residence in Paris }\end{array}$ \\
\hline Liverpool $^{11}$ & $\begin{array}{l}\text { Digestion and phase } \\
\text { contrast microscopy }\end{array}$ & 300 & $\begin{aligned} & 94 \% \text { with } \\
> & 1000 / \mathrm{g}\end{aligned}$ & $\begin{array}{l}100 \text { Mesothelioma, } 100 \text { lung } \\
\text { cancer, } 100 \text { necropsies }\end{array}$ & $\begin{array}{l}\text { Significant increase in the } \\
\text { mesothelioma cases }\end{array}$ \\
\hline Chicago $^{12}$ & $\begin{array}{l}\text { Digestion and micro } \\
\text { filtration }\end{array}$ & 252 & $96 \%$ & $\begin{array}{l}\text { Urban population aged } \\
\text { over } 40\end{array}$ & $\begin{array}{l}\text { Prevalence related to type } \\
\text { of occupation }\end{array}$ \\
\hline Rural Tennessee $^{13}$ & $\begin{array}{l}\text { Digestion and filtration } \\
\text { of } 5-20 \mathrm{~g} \text { of lung }\end{array}$ & 124 & $95 \%$ & $\begin{array}{l}100 \text { Necropsies } 24 \text { pulmonary } \\
\text { neoplasms }\end{array}$ & No increase in neoplastic series \\
\hline Baltimore ${ }^{14}$ & Digestion & 253 & $91 \%$ & $\begin{array}{l}\text { Divided into } 3 \text { decades: } \\
1940-91950-91970-2\end{array}$ & $\begin{array}{l}\text { Prevalence in } 1940 \text { s } \\
\text { only } 41 \%\end{array}$ \\
\hline Malmo, Sweden ${ }^{15}$ & $30-\mu$ sections and smear & 97 & $48 \%$ & Consecutive necropsies & $\begin{array}{l}\text { Increased prevalence in cases } \\
\text { with pleural plaques }\end{array}$ \\
\hline London ${ }^{16}$ & $30-\mu$ section $^{5}$ & 394 & $37 \%$ & $\begin{array}{l}\text { Consecutive necropsies on } \\
216 \text { men and } 178 \text { women }\end{array}$ & $\begin{array}{l}\text { Compares prevalence with } \\
\text { occupation and address of } \\
\text { domicile }\end{array}$ \\
\hline Jerusalem ${ }^{17}$ & Smears & 100 & $26 \%$ & $\begin{array}{l}\text { Consecutive adult } \\
\text { necropsies }\end{array}$ & $\begin{array}{l}\text { More frequent in Ashkenazi } \\
\text { Jews }\end{array}$ \\
\hline London $^{18}$ & $30-\mu$ sections & $4 \times 100$ & $20 \%$ & $\begin{array}{l}\text { Consecutive necropsies in } \\
1936,1946,1956 \text {, and } 1966\end{array}$ & $\begin{array}{l}\text { Increasing prevalence with } \\
\text { each decade }\end{array}$ \\
\hline Michigan $^{19}$ & $7-\mu$ sections and scrapings & 100 & $18 \%$ & Consecutive necropsies & \\
\hline Copenhagen ${ }^{20}$ & $5-\mu$ sections & 198 & $7 \%$ & Random necropsy series & $\begin{array}{l}\text { Poor correlation with pleural } \\
\text { plaques }\end{array}$ \\
\hline Boston $^{21}$ & $\begin{array}{l}\text { Digestion and micro } \\
\text { filtration }\end{array}$ & 28 & $39 \%$ & $\begin{array}{l}\text { Necropsy material from } \\
1928-32\end{array}$ & \\
\hline $\begin{array}{l}\text { Duluth and New } \\
\text { York }^{22}\end{array}$ & Ashed $20-\mathrm{mm}^{3}$ sections & 378 & $67-80 \%$ & Female necropsies $1953-73$ & $\begin{array}{l}\text { Compares prevalence before } \\
\text { and after contamination of } \\
\text { Duluth water supply }\end{array}$ \\
\hline Chicago $^{23}$ & Digestion & 130 & & $\begin{array}{l}100 \text { control lungs and } \\
30 \text { lung cancers }\end{array}$ & $\begin{array}{l}\text { More asbestos in cases of } \\
\text { cancer, but more of these were } \\
\text { men }\end{array}$ \\
\hline
\end{tabular}

$61 \%$ showed light contamination and $26 \%$ were asbestos-free (table 5).

\section{Discussion}

There is abundant evidence that heavy exposure to asbestos causes the pulmonary fibrosis known as asbestosis. ${ }^{4}$ Similarly, there are many reports of bronchial carcinoma and mesothelioma. ${ }^{56}$ This report is concerned with the prevalence and concentration of asbestos bodies in lungs with and without bronchial carcinomas. Even in asbestos workers the incidence of carcinoma of the lung is low in non-smokers, being estimated at between 1.4 and 4.8 times the risk of the non-exposed non-smoker, ${ }^{78}$ which is still less than half that of the non-exposed smoker. It is the combination of asbestos exposure and cigarette smoking that raises the incidence of lung cancer almost a hundred-fold above the level of the non-exposed non-smoker. ${ }^{9}$ The increased risk is related to the amount of asbestos exposure and the number of cigarettes smoked. A major objective of retrospective studies, such as the present one, is to determine the role of low-dose asbestos exposure in the aetiology of lung cancers at different times and at different places. In 1970 a table of earlier reports of asbestos body prevalence was published $;^{1}$ since then more studies from around the world have confirmed the increasing frequency with which asbestos is to be found in human lungs (table 6). Two of these reported more asbestos contamination in patients with lung cancer than in controls, ${ }^{1023}$ but most have, like our study, shown no significant difference between patients with and without cancer. ${ }^{11-1316}$ None of the studies, however, has separated their patients with lung cancer into their histological subtypes. Several papers have reported an excess of adenocarcinomas and small cell carcinomas in workers exposed to asbestos. ${ }^{24-27} \mathrm{We}$ found a higher level of asbestos contamination in the adenocarcinomas (tables 1 and 3 ) and, although it was not sufficient to reach the $5 \%$ significance level, this observation raises the possibility that if a large series of adenocarcinomas were to be considered then an association with asbestos contamination would be demonstrable.

It has been established that the great majority of ferruginous bodies, excluding those with black or yellow cores, have at their centre a fibre of amphibole asbestos, ${ }^{28} 29$ and most non-coated fibres seen by light microscopy are also amphiboles, chrysotile fibres being very hard to see even with phase contrast microscopy. ${ }^{11}$ We have shown that the digestion method is a more sensitive way of detecting coated fibres than inspection of $30-\mu \mathrm{m}$ unstained sections. Sections showed bodies in only $6 \%$ of the Wellington lungs, whereas digestion showed them in $75 \%$. The overall frequency of asbestos in men was not significantly different 
$(83 \%)$ in Southampton, but the frequency of heavily contaminated male lungs $(24 \%)$ was much higher in Southampton than in Wellington (6\%). Presumably this is because a larger percentage of the specimens came from workers who had some occupational exposure to asbestos in the dockland areas of Southampton and Portsmouth than in the relatively agricultural district of Wellington. It also suggests that the general background exposure of the whole population is not significantly different, despite the greater occupational usage. This view is further supported by the results of the small female series in Southampton in 1981 , of which $61 \%$ were lightly contaminated compared with $58 \%$ of the Wellington series and $26 \%$ asbestos-free compared with $37 \%$ in Wellington.

It seems that contamination with asbestos may be a co-factor in the aetiology of some cases of adenocarcinoma in the Southampton area (table 1), where a quarter of the male cases of adenocarcinoma were found to be positive by $30-\mu$ section, compared with only $16 \%$ of other histological types. A similar trend for a higher proportion of heavily contaminated cases to be found among the adenocarcinomas was apparent in the Wellington results (table 4), though this also was not significant at the $5 \%$ level. It seems pertinent that recent reports from America ${ }^{30}$ and London ${ }^{31}$ have suggested an increasing incidence of adenocarcinomas of the lung. Is it just coincidence that this has occurred $20-30$ years after a great increase in world asbestos production, which more than doubled between 1957 and 1976, and has increased tenfold since before the second world war? There have been several reports of the fibre content of lungs removed in recent years being higher than it used to be two or more decades ago..$^{131720} \mathrm{We}$ were unable, however, to show any increase in either prevalence or intensity of contamination in Wellington between 1956 and 1977. This was expected, as there had been no significant increase in industrialisation in the area during that period. Neither, it may be added, has there been any increase in the proportion of adenocarcinomas.

We were surprised to observe the frequent involvement of young people's lungs, even those of the two 17-year-olds in the series having some asbestos bodies present, while $80 \%$ of cases under 30 and $85 \%$ of all cases under 40 contained some asbestos. In concurrence with most other reports, men had significantly more contamination than women $(78 \%$ of men contrasting with $65 \%$ of women), and that contamination appeared to be heavier (moderate and heavy deposits in $36 \%$ of men and only $10 \%$ of women). The low levels of contamination found in $58 \%$ of women may reflect the many domestic uses of asbestos.

In conclusion, we think that quantitative studies of concentrations of asbestos in human tissues should continue to be made periodically in different parts of the world. They not only provide baselines from which to monitor future levels but may give relatively early warning of association with particular diseases. It must be emphasised, however, that this study provides no evidence to support alarmist views of widespread danger from asbestos, but implies that the present-day concentrations in the community outside the asbestos industry are responsible for no more than a very small amount of lung cancer and quite possibly not even that.

The Wellington survey was assisted by a grant from the Wellington Medical Research Foundation. We are most grateful to Dr V Siskind, reader in medical statistics at Queensland University, for the statistical analysis and much valued advice.

\section{References}

' Penman HG, Thomson KJ. Pulmonary asbestos in Dunedin, New Zealand, assessed by two methods. Pathology 1970;2:175-82.

${ }^{2}$ Gold C. A simple method for detecting asbestos in tissue. J Clin Pathol 1967;20:674. (Abstract.)

${ }^{3}$ Bartholomew DJ. A test of homogeneity for ordered alternatives. Biometrika 1959;46:36-48.

4 Hillerdal G. Pleural plaques. Occurrence, exposure to asbestos and clinical importance. Acta Universitatis Upsaliensis 1980;363:5-227.

5 Doll R. Mortality from lung cancer in asbestos workers. $\mathrm{Br} \mathrm{J}$ Ind Med 1955;12:81-6.

- Wagner JC, Sleggs CA, Marchand P. Diffuse pleural mesothelioma and asbestos exposure in the North Western Cape Province. Br J Ind Med 1960;17:260-71.

${ }^{7}$ Meurman LO, Kiviluoto R, Hakama M. Mortality and morbidity among the working population of anthophyllite asbestos miners in Finland. Br J Ind Med 1974;31:105-12.

- Selikoff IJ, Hammond EC, Churg J. Asbestos exposure, smoking and neoplasia. JAMA 1968;204:104-12.

'Selikoff IJ, Hammond EC. Asbestos and smoking. JAMA 1979;242:458-9.

"Bignon J, Goni J, Bonnaud G, Jaurand MC, Dufour G, Pinchon MC. Incidence of pulmonary ferruginous bodies in France. Environ Res 1970;3:430-42.

"Whitwell F, Scott J, Grimshaw M. Relationship between occupations and asbestos-fibre content of the lungs in patients with pleural mesothelioma, lung cancer, and other diseases. Thorax 1977;32:377-86.

12 Churg A, Warnock ML. Correlation of quantitative asbestos body counts and occupation in urban patients. Arch Pathol Lab Med 1977;101:629-34.

13 Breedin PH, Buss DH. Ferruginous (asbestos) bodies in the lungs of rural dwellers, urban dwellers and patients with pulmonary neoplasia. South Med J 1976;69:401-4.

14 Bhagavan BS, Koss LG. Secular trends in prevalence and concentration of pulmonary asbestos bodies-1940-1972. Arch Pathol Lab Med 1976;100:539-41.

15 Hägerstrand I, Seifert B. Asbestos bodies and pleural plaques in human lungs at autopsy. Acta Pathol Microbiol Scand (A) 1973;81:457-60. 
${ }^{16}$ Doniach I, Swettenham KV, Hathorn MKS. Prevalence of asbestos bodies in a necropsy series in East London: association with disease, occupation and domiciliary address. Br J Ind Med 1975;32:16-30.

${ }^{17}$ Polliack A, Sachs MI. Prevalence of asbestos bodies in basal lung smears. Isr J Med Sci 1968;4:223-6.

${ }^{18} \mathrm{Um} \mathrm{CH}$. Study of the secular trend in asbestos bodies in lungs in London 1936-66. Br Med J 1971;ii:243-52.

19 Dicke TE, Naylor B. Prevalence of "'asbestos" bodies in human lungs at autopsy. Dis Chest 1969;56:122-5.

${ }^{20}$ Francis D, Jussuf A, Mortensen T, Sikjaer B, Viskum K. Hyaline pleural plaques and asbestos bodies in 198 randomised autopsies. Scand J Respir Dis 1977;58:193-6.

${ }^{21}$ Gordon P, Rosen PP, Savino A. The ferruginous body contents of lungs at autopsy in Boston, 1928-1932. Acta Cytol (Baltimore) $1976 ; 20: 521-4$.

${ }^{22}$ Auerbach O, Hammond EC, Selikoff IJ, Parks VR, Kaslow DG, Garfinkel L. Asbestos bodies in lung parenchyma in relation to ingestion and inhalation of mineral fibres. Environ Res 1977;14:286-304.

${ }^{23}$ Warnock ML, Churg AN. Association of asbestos and bronchogenic carcinoma in a population with low asbestos exposure. Cancer 1975;35:1236-42.
24 Hasan FM, Nash G, Kazemi H. Asbestos exposure and related neoplasia. The 28-year experience of a major urban hospital. Am J Med 1978;-65:649-54.

${ }^{25}$ Huuskonen MS. Clinical features, mortality and survival of patients with asbestosis. Scand J Work Environ Health 1978;4:265-74.

${ }^{26}$ Whitwell F, Newhouse ML, Bennett DR. A study of histological cell types of lung cancer in workers suffering from asbestos is in the United Kingdom. Br J Ind Med 1974;31:292-303.

${ }^{27}$ Hillerdal G, Nõu E. Occupation and bronchial carcinoma. Scand $J$ Respir Dis 1979;60:76-82.

${ }^{28}$ Churg A, Warnock ML. Analysis of the cores of ferruginous (asbestos) bodies from the general population. III Patients with environmental exposure. Lab Invest 1979;40:622-6.

${ }^{29}$ Churg AM, Warnock ML. Asbestos and other ferruginous bodies. Their formation and clinical significance. Am J Pathol 1981;102:447-56.

${ }^{30}$ Vincent RG, Pickren JW, Lane WW, et al. The changing histopathology of lung cancer. Cancer 1977;39:1647-55.

${ }^{31}$ Belcher JR. Adenocarcinoma of the bronchus. Thorax 1981;36:708. (Abstract.) 